\title{
ГОТОВНІСТЬ МЕДСЕСТЕР ДО ЕЛЕКТРОННОГО МЕТОДУ ОБЛІКУ ЗА УМОВ РЕФОРМУВАННЯ ГАЛУЗІ
}

\author{
О. Н. Литвинова, О. І. Гарасимів \\ ДВНЗ «Тернопільський державний медичний університет \\ імені І. Я. Горбачевського МОЗ Украӥни" \\ Борщівська центральна районна комунальна лікарня
}

У статті йдеться про готовність медсестер до електронного методу обліку за умов реформування галузі охорони здоров’я. Дано оцінку реальної ситуації та перспективи використання електронного обліку в системі медичної допомоги та участь у ньому медсестер.

\section{READINESS OF NURSES TO THE ELECTRONIC ACCOUNTING METHODS IN THE CONDITIONS OF REFORMING THE HEALTH SECTOR}

\author{
O. N. Lytvynova, O. I. Garasimiv \\ I. Horbachevsky Ternopil State Medical University \\ Borshchiv Central District Hospital
}

The article deals with the readiness of nurses to use electronic methods of accounting, in the context of reforming the health sector. The estimation of the real situation and prospects of using electronic accounting in the system of medical care and participation in it by nurses is given.

Вступ. На сьогодні все частіше постає питання електронного обліку, що і $\epsilon$ головним інноваційним елементом системи охорони здоров'я.

Електронний реєстр пацієнтів $є$ основою інформаційної електронної системи охорони здоров'я (E-Health) [1]. Його створення потребує системного стратегічного підходу ряду державних інституцій з серцевиною МОЗ України. Запровадження електронної системи охорони здоров'я гарантуватиме прозорість системи та дасть можливість забезпечити моніторинг ефективності лікувального процесу і відрегулювати наступництво тощо. Роль у цьому процесі медичної сестри висвітлено в даній статті.

Основна частина. Електронний реєстр пацієнтів це лише частина глобальної інформаційної системи медичної допомоги. Якщо розглядати кожного громадянина як потенційного пацієнта, то такий електронний реєстр замінить перепис населення і статистичні служби та, зрештою, і органи державної реєстрації актів цивільного стану та паспортні столи. 3 позицій держави - дуже вигідно створити єдиний

(c) О. Н. Литвинова, О. І. Гарасимів, 2018 реєстр, який містив би повну базу даних про громадянина, адже у цьому разі та ж сама інформація не розпорошуватиметься між різними відомствами та не дублюватиметься. До речі, медична складова такого реєстру була 6 найбільшою і найдинамічнішою [2].

Власник бази електронного реєстру пацієнтів повинен мати сертифікат встановленого зразка про ії реєстрацію у Державному реєстрі баз персональних даних [3]. Знову ж таки виникає питання: скільки буде таких власників - лише МОЗ України чи й обласні департаменти охорони здоров'я, асоціації фахівців, окремі заклади охорони здоров'я або центри ПМСД [4].

Ми провели самостійне дослідження готовності медичних сестер до роботи з електронним обліком у системі медичної допомоги. Для цього було розроблено індивідуальну програму дослідження - анкету з переліком запитань щодо готовності роботи з електронним обліком. У дослідженні взяли участь медсестри районних лікарень Тернопільської області. Після опрацювання і вибракування для аналізу було відібрано 100 анкет, за результатами яких і було зроблено висновки щодо готовності медсестер до роботи з електронним обліком. 
У результаті дослідження виявлено, що на рівні оператора вміє користуватись комп'ютером $(56 \pm 4,96) \%$, орієнтуються в простих офісних програмах $(9 \pm 2,86) \%$ респондентів. Вільний доступ до комп'ютера на роботі мають лише $(19 \pm 2,75)$ \% медсестер. 3 електронною системою E-Health ознайомлені лише $(34 \pm 4,74) \%$ опитаних медсестер. Звідки варто зробити висновки про необхідність запровадження освітніх програм навчання медсестер із можливостями електронного обліку в системі охорони здоров'я, зокрема із електронною системою E-Health.

На сьогодні працювати з електронним реєстром пацієнтів не готова жодна медсестра і $(33 \pm 4,7) \%$ не готові й в перспективі. Після проходження курсів спеціалізації готові працювати з електронним обліком $(24 \pm 4,27)$ \% медсестер, $(42 \pm 4,94)$ \% готові в майбутньому освоїти цей вид діяльності самостійно.

У ймовірність захисту даних при електронному документообігу вірять лише $(27 \pm 4,44) \%$ медсестер, $(73 \pm 4,44) \%$ категорично відкидають таку можливість.

У те, що система E-Health дозволить перевести всі медичні документи з паперового формату в цифровий вірять $(80 \pm 4,0) \%$ респондентів. Що це можливо лише у випадку, коли до електронного ресурсу залучаться всі заклади охорони здоров'я вважають $(70 \pm 4,58) \%$ медсестер. $(67,5 \pm 4,68)$ \% медсестер вважають цілком реальним, що система E-Health дасть змогу контролювати, наскільки ефективно держава витрачає кошти на охорону здоров'я.

Версію щодо залежності зарплати медпрацівників від кількості зареєстрованих пацієнтів підтримує $(75 \pm 4,33)$ \% медсестер, а у можливість записуватися на прийом у зручний час для пацієнтів вірить лише $(65,5 \pm 4,68) \%$ респондентів.

\section{СПИСОК ЛІТЕРАТУРИ}

1. Про затвердження Порядку ведення електронного реєстру пацієнтів Вінницької, Дніпропетровської, Донецької областей та м. Києва : наказ МОЗ від 30 серпня 2012 р. № 666 [Електронний ресурс]. - Режим доступу : http://zakon.golovbukh.ua/regulations/1521/8459/ 10275/470044/. - Назва з екрана.

2. Литвинова О. Н. Реєстр пацієнтів в Україні / О. Н. Литвинова // Газета «Ваше здоров'я». - 2016. 09 грудня. - № 49-50 (1385-1386). - С. 10-11.
Через ненадійність електронної системи $(40 \pm 4,9) \%$ медсестер вважають за доцільне спочатку заповняти папери, а потім переносити всю цю інформацію в електронну систему. Так само вважають доцільним подвійний облік $(6 \pm 2,37)$ \% медсестер, але з причини, що в архіви варто здавати паперові документи або тому, що ніхто не відміняв паперове діловодство. I про те, що електронного діловодства достатньо, а папери це вчорашній день вважають $(46 \pm 4,98)$ \% опитаних.

щодо фінансування впровадження електронної охорони здоров'я, то $(57 \pm 4,95)$ \% медсестер вважають основним фондотримачем Міністерство охорони здоров'я України, $(12 \pm 3,25)$ \% - Національну службу здоров'я, $(21 \pm 4,07) \%$ - Міжнародні грантові програми, $(7 \pm 2,55) \%$ - місцеві адміністрації і лише $(3 \pm 1,7)$ \% вважають, що ці витрати мають лягти на плечі закладу охорони здоров'я.

Прогнозні терміни, коли має запрацювати електронний реєстр пацієнтів в Україні, респонденти в більшості $(57 \pm 4,95) \%$ встановили, що не раніше 2020 р., $(24 \pm 4,27) \%$ вважають, що у далекому майбутньому, $(17 \pm 3,76) \%$ мають оптимістичне бачення і вважають, що запрацює електронний реєстр у 2018 р.

Висновки. Результати дослідження готовності медичних сестер до роботи з електронним обліком у системі медичної допомоги показали, що трохи більше 65 \% медсестер мають навики роботи з комп'ютером. Більше третини медсестер знайомі з електронною системою E-Health. На сьогодні працювати з електронним реєстром пацієнтів не готова жодна медсестра і $(33 \pm 4,7) \%$ не готові й в перспективі. Такі дані свідчать про необхідність запровадження освітніх програм навчання медсестер із можливостями електронного обліку в системі охорони здоров'я, зокрема із електронною системою E-Health.

3. Закон «Про доступ до публічної інформації» [Електронний ресурс] / (Відомості Верховної Ради України (ВВР). 2011. - № 32. - С. 314). - Режим доступу : http://zakon3.rada. gov.ua/laws/show/2939-17. - Назва з екрана.

4. Про затвердження Положення про електронний реєстр пацієнтів : Постанова Кабінету Міністрів України від 06 червня 2012 р. № 546 [Електронний ресурс]. - Режим доступу : http://zakon5.rada.gov.ua/laws/show/5462012-\%D0\%BF. - Назва з екрана. 